\title{
Fertility status of irrigated soils of coastal Gir Somnath district of Gujarat
}

\author{
J.V. POLARAAND R.B. CHAUHAN
}

Received : 23.07.2015; Revised : 01.11.2015; Accepted : 16.11.2015

MEMBERS OF RESEARCH FORUM:
Corresponding author :
J.V. POLARA, Department of
Agricultural Chemistry and Soil
Science, Junagadh Agricultural
University, JUNAGADH (GUJARAT)
INDIA
Email: jvpolara @jau.in
Co-authors :
R.B. CHAUHAN, Department of
Agricultural Chemistry and Soil
Science, Junagadh Agricultural
University, JUNAGADH (GUJARAT)
INDIA
Email : chauhanravi3612@ gmail.
com

\section{Summary}

Thirty representative surface $(0-15 \mathrm{~cm})$ soil samples were collected from cultivated farmer's field of each taluka of Gir Somnath district viz., Talala, Veraval, Sutrapada, Kodinar, Gir Gadhada and Una during 2014. The chemical analysis of 180 surface samples indicates that soil were deficient with respect to available $\mathrm{N}$ and $\mathrm{P}_{2} \mathrm{O}_{5}$, whereas medium in available $\mathrm{S}$ and high in available $\mathrm{K}_{2} \mathrm{O}$ status. Among the DTPA extractable micronutrients, $\mathrm{Mn}$ and $\mathrm{Cu}$ were found sufficient, whereas the soils were medium in $\mathrm{Fe}$ and $\mathrm{Zn}$. The nutrient index values were low for available $\mathrm{N}$ (1.20) and $\mathrm{P}_{2} \mathrm{O}_{5}$ (1.27), medium for available $\mathrm{S}$ (1.74), $\mathrm{Fe}$ (2.24) and $\mathrm{Zn}$ (2.17) and high for available $\mathrm{K}_{2} \mathrm{O}$ (2.64), $\mathrm{Mn}$ (2.79) and $\mathrm{Cu}$ (3.00) in the soils of Gir Somnath district.

Key words : Available macronutrients, DTPA extractable micronutrients, Nutrient index

How to cite this article : Polara, J.V. and Chauhan, R.B. (2015). Fertility status of irrigated soils of coastal Gir Somnath District of Gujarat. Asian J. Soil Sci., 10(2) : 263-265. 